\title{
PKM Teknologi Fermentasi Tape Jusinta di Pondok Pesantren Puteri Yatama Mandiri Kabupaten Gowa
}

\author{
Nurhayani H. Muhiddin ${ }^{1}$, Ratnawaty Mamin ${ }^{2}$, Hasanuddin ${ }^{3}$ \\ 1,2,3 Program Studi Pendidikan IPA, Fakultas MIPA, Universitas Negeri Makassar
}

\begin{abstract}
The target partners in the Public Partnership Program (PKM) of Jusinta Tape Fermentation technology are students at the XII grade SMA Yatama Mandiri Islamic Boarding School, Gowa Regency. The location of the Islamic boarding school is in the area of Pallangga Subdistrict, Gowa Regency, which has the first highest cassava production and second highest sweet potatoes production land in South Sulawesi.. The implementation of activities is supported by the field of expertise of the implementing team related to the results of research in the form of a tape product called "Tape Jusinta" (Muhiddin, et al., 2018). This tape is made through the fermentation process of a mixture of purple sweet potato tubers and cassava roots using a local ragi tape starter. The process of making tape from purple sweet potato (Ipomoea batatas L.) and cassava roots (Manihot esculenta Crantz) with a local ragi tape starter, has received patent certificate in January 2020. Another thing that supports the potential of students who really need knowledge development and skills to grow economically productive businesses with Islamic boarding schools located in sweet potato and cassava production centers. The output target that is expected to be achieved in this PKM activity is that students have the knowledge and skills in producing Jusinta Tape through fermentation technology. The results of the activity are expected to be developed into a learning tool for biotechnology materials. The methods used are: lectures, demonstrations, discussions, practice and mentoring. The instruments used to determine the participants' responses to the Tape Jusinta fermentation technology training were questionnaires, observation, interviews, and documentation. The results achieved were that the participants could easily understand the processing of purple sweet potato and cassava roots into Tape Jusinta through fermentation technology. As many as $60 \%$ of the participants from the teacher group answered that the Tape Jusinta fermentation technology was in accordance with the students' abilities and was suitable to be applied in biotechnology learning. The organoleptic test results show that the Tape Jusinta product has a light purple color with an average of 4.4, the aroma of alcohol is less sharp with an average of 4.2, a soft texture with an average of 8.6, a slightly sour taste with an average of 4.4, the taste is quite sweet on average 6.5 , and product palatability by the society is well received with an average of 8.9 .
\end{abstract}

Keywords: Students, Islamic Boarding Schools, Tape Jusinta, Fermentation Technology

\section{PENDAHULUAN}

Pondok Pesantren Putri Yatama di kecamatan Pallangga Kabupaten Gowa merupakan salah satu panti sosial asuhan anak yang menampung khusus santriwati dari kalangan anak yatim. Jumlah santriwati tingkat SMP sebanyak 218 anak dan tingkat SMA sebanyak 173 anak dengan Pembina sebanyak 28 orang. Lokasinya berada di kecamatan Pallangga, dengan luas area sekitar 4,7 Ha. Biaya operasional yang dikelola oleh Pembina panti asuhan berasal dari berbagai donator. Panti asuhan ini berada di wilayah Kecamatan Pallangga Kabupaten Gowa yang memiliki lahan produksi ubi kayu tertinggi pertama dan urutan kedua pada produksi ubi jalar se-Sulawesi Selatan. Lokasi pondok yang berada di wilayah pusat produksi ubi kayu dan ubi jalar, menjadikan santriwati sangat potensial untuk diberdayakan sebagai mitra dalam produksi "Tape Jusinta" melalui teknologi fermentasi.

Kegiatan Program Kemitraan Masyarakat (PKM) ini dilaksanakan oleh Tim Pelaksana kegiatan dari Program studi Pendidikan IPA FMIPA UNM. Mitra pada kegiatan ini adalah santriwati kelas XII SMA Pesantren Putri Yatama Mandiri Kabupaten Gowa

Masalah dalam pengabdian ini yang pertama adalah santriwati yang merupakan anak yatim dengan keterbatasan secara finansial, keterbatasan pengetahuan dan keterampilan untuk menghasilkan produk bernilai ekonomi. Permasalahan lain adalah biaya operasional pondok pesantren hanya berasal dari donator. Sementara lokasi Pondok Pesantren Putri Yatama terletak di wilayah pusat produksi tanaman hortikultura terutama ubi jalar 
dan ubi kayu. Produksi ubi kayu di Gowa adalah tertinggi pertama dan urutan kedua pada produksi ubi jalar se-Sulawesi Selatan (Saudagarnews.id, Gowa, oktober 2018). Produksi ubi kayu di Kecamatan Pallangga sebesar 223 ton/Ha dan ubi jalar sebesar 196 ton/Ha (BPS Gowa, 2017).

Sumber daya manusia yang ada di Pondok Pesantren Putri Yatama perlu dikembangkan guna menghasilkan lulusan yang lebih produktif dalam mempersiapkan diri disaat mereka kembali ke masyarakat. Melihat potensi santriwati dan lokasi Pondok Pesantren di wilayah produksi tanaman horikultura Kecamatan Pallangga Kabupaten Gowa, maka salah satu keterampilan yang perlu dilatihkan ke santriwati adalah produksi Tape Jusinta melalui teknologi fermentasi.

Pelaksanaan kegiatan didukung oleh bidang keahlian tim pelaksana terkait hasil penelitian berupa produk tape yang diberi nama "Tape Jusinta" (Muhiddin, dkk., 2018). Tape ini dibuat melalui proses fermentasi campuran umbi ubi jalar ungu dan umbi ubi kayu menggunakan starter ragi tape lokal. Proses pembuatan tape dari ubi jalar ungu (Ipomoea batatas L.) dan umbi ubi kayu (Manihot esculenta Crantz) dengan starter ragi tape lokal, telah mendapatkan sertifikat paten HKI pada Januari tahun 2020.

Ragi tape adalah istilah umum untuk starter yang digunakan untuk membuat tape, baik tape singkong maupun tape beras ketan. Umumnya ragi tape yang digunakan di Indonesia mengandung lebih dari satu jenis mikroorganisme, baik khamir, kapang, maupun bakteri. Menurut Ajayi at al. (2016) bahwa fermentasi adalah konversi karbohidrat menjadi alkohol dan karbon dioksida atau asam organik menggunakan khamir, bakteri atau kombinasi dalam kondisi anaerob. Manfaat utama fermentasi adalah konversi gula dan karbohidrat lain menjadi produk akhir yang dapat digunakan.

Jenis ragi tape yang digunakan sebagai starter dalam fermentasi Tape Jusinta adalah hasil seleksi dari ragi tape lokal yang diperoleh dari beberapa daerah di Provinsi Sulawesi Selatan dan Sulawesi Tenggara. Ragi tape yang menghasilkan mutu organolepik dan kandungan nutrisi terbaik dipilih untuk produksi Tape Jusinta. Produk ini merupakan makanan yang dapat dikonsumsi langsung sebagai makanan pendamping, dan dapat dijadikan bahan baku pembuatan es krim. Hasil uji daya terima (palatability) panelis terhadap Tape Jusinta hasil fermentasi ragi tape B asal Kabupaten Bone tidak berbeda dengan Tape Jusinta hasil fermentasi ragi tape $\mathrm{A}$ dan $\mathrm{C}$, namun tape jusinta hasil fermentasi ragi tape $\mathrm{C}$ berbeda dengan hasil fermentasi ragi tape D dan E. Dengan demikian Tape Jusinta hasil fermentasi ragi tape B lebih disukai daripada Tape Jusinta hasil fermentasi ragi tape $\mathrm{A}, \mathrm{C}, \mathrm{D}$ dan $\mathrm{E}$ dengan rata-rata penilaian panelis tertinggi yaitu 4.15. Kuantitas mikroorganisme ragi tape $\mathrm{B}$ yaitu jenis kapang sebanyak $1.0 \times 10^{4} \mathrm{cfu} / \mathrm{g}$, khamir $8.0 \times 10^{3} \mathrm{cfu} / \mathrm{g}$ dan bakteri 5.7 x $10^{4} \mathrm{cfu} / \mathrm{g}$ (Muhiddin, dkk., 2019).

Mutu organoleptik Tape Jusinta yaitu warna agak cerah, aroma agak beralkohol, tekstur lunak, serta rasa agak asam dan agak manis. Kandungan nutrisi Tape Jusinta antara lain : kadar protein 1.55 $\%$, kadar air $68.61 \%$, kadar lemak $0.16 \%$, kadar serat $0.84 \%$, kadar pati $27.85 \%$, Kadar gula 10.05 $\%$, kadar abu $0.98 \%$, padatan terlarut $13.66 \%$, kadar alkohol $0.77 \%$, dan kadar asam laktat 0.72 $\%$ (Muhiddin dkk., 2018).

Kegiatan ini akan mengukur tingkat pengetahuan dan keterampilan santriwati melalui pengisian angket respons peserta terhadap pelatihan teknologi fermentasi Tape Jusinta. Kualitas produk "Tape jusinta" diukur melalui uji organoleptik produk tape yang dihasilkan oleh peserta pelatihan.

Target luaran yang diharapkan dicapai dalam kegiatan Program Kemitraan Masyarakat khususnya santriwati Pondok Pesantren Putri Yatama Mandiri Kabupaten Gowa adalah dapat memberikan tambahan pengetahuan dan keterampilan kepada santriwati dalam produksi Tape Jusinta melalui teknologi fermentasi. Keterampilan pembuatan Tape Jusinta merupakan salah satu bagian dari penerapan materi pembelajaran bioteknologi. Hasil kegiatan dipublikasikan melalui madia elektronik dan jurnal ilmiah. Selain itu, hasil kegiatan ini juga diharapkan dapat dikembangkan menjadi salah satu 
perangkat pembelajaran pada materi Bioteknologi di Sekolah Menengah Atas Pondok Pesantren Putri Yatama Mandiri Kabupaten Gowa.

Target luaran yang diharapkan dicapai dalam kegiatan PKM ini adalah santriwati memiliki pengetahuan dan keterampilan dalam teknologi fermentasi Tape Jusinta. Hasil kegiatan ini dapat dikembangkan menjadi salah satu perangkat pembelajaran pada materi Bioteknologi. Selain pengetahuan dan keterampilan tentang teknologi fermentasi Tape Jusinta, santriwati juga akan diedukasi mengenai cara penyajian untuk konsumsi langsung serta pengemasan dan penyimpanan untuk dijual.

Partisipasi mitra sasaran dievaluasi melalui keaktifan dalam diskusi, keterampilan dalam proses pembuatan tape jusinta. Keterampilan peserta dalam memproduksi tape jusinta dinilai dari kualitas organoleptik produk.

Tujuan umum pengabdian Program Kemitraan Masyarakat melalui pelatihan teknologi fermentasi Tape Jusinta adalah mendeskripsikan hasil kegiatan PKM teknologi fermentasi Tape Jusinta pada santriwati SMA kelas XII serta guru-guru pembina mata pelajaran di pesantren tersebut. Instrumen yang digunakan untuk mengetahui respons peserta terhadap pelatihan teknologi fermentasi Tape Jusinta adalah angket, observasi, wawancara, dan dokumentasi. Teknik analisis data secara deskriptif kuantitatif yang dikaitkan dengan hasil wawancara dan pengamatan.

Pelatihan ini dilakukan untuk berbagi ilmu kepada santriwati SMA kelas XII serta guru-guru pembina mata pelajaran di pesantren tersebut tentang cara aplikasi bioteknologi dalam mengolah umbi ubi jalar ungu dan umbi ubi kayu melalui teknologi fermentasi menggunakan ragi tape lokal untuk memproduksi Tape Jusinta. Pelatihan ini diharapkan dapat meningkatkan pengetahuan dan keterampilan peserta sehingga memiliki kemampuan memproduksi Tape Jusinta. Peserta dari kalangan guru diharapkan dapat meneruskan ilmu dan keterampilan yang diperoleh ke peserta didik melalui pembelajaran bioteknologi dan ke masyarakat di sekitar mereka.

\section{METODE YANG DIGUNAKAN}

a. Agar mitra memiliki pengetahuan dan keterampilan dalam teknologi fermentasi Tape Jusinta, maka metode yang digunakan adalah ceramah, demonstrasi, diskusi, praktek dan tanya jawab.

b. Agar mitra terampil menyiapkan substrat dan inokulasi starter ragi tape, maka metode yang digunakan adalah demonstrasi, diskusi, praktek dan tanya jawab.

c. Agar mitra memiliki kemampuan memproduksi Tape Jusinta, maka metode yang digunakan adalah demonstrasi, diskusi, tanya jawab, praktek dan pendampingan mitra.

\section{PELAKSANAAN DAN HASIL KEGIATAN}

Kegiatan pengabdian pada masyarakat ini dilaksanakan oleh Tim Pelaksana kegiatan dari Program studi Pendidikan IPA FMIPA UNM dengan mitra Pesantren Putri Yatama Mandiri. Mitra sasaran pada Program Kemitraan Masyarakat ini difokuskan pada santriwati kelas XII SMA yang berdomisili di Pondok Pesantren Puteri Yatama Mandiri dan memilih menetap di pondok selama masa pandemi Covid 19. Selain santriwati beberapa guru pembina mata pelajaran di Pondok Pesantren ini juga berpartisipasi sebagai peserta pada kegiatan ini. Kegiatan pengabdian melalui pelatihan teknologi fermentasi Tape Jusinta berlangsung pada tanggal 8 - 9 September 2020 di Laboratorium IPA SMA Pesantren Puteri Yatama Mandiri .

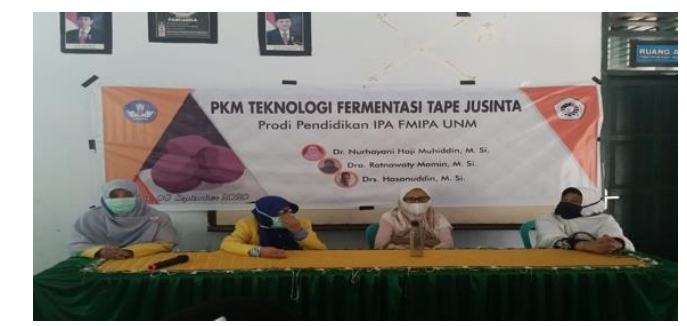

Gambar 1. Pembukaan PKM Teknologi Fermentasi Tape Jusinta oleh Tim PKM bersama Pimpinan dan Ketua Yayasan Pesantren Puteri Yatama Mandiri

Pembukaan kegiatan pengabdian kepada masyarakat dihadiri oleh Pimpinan Pondok Pesantren ibu Dra. Hj. Muliati Daud, M.Hum., Ketua Yayasan Pondok Pesantren Yatama ibu 
Hj. Nurasia Hafidz, Wakil Kepala Sekolah SMA Abdul Rahim, S.Pd., M.Pd. serta beberapa Guru SMA. Pimpinan dan Ketua Yayasan dalam sambutannya sangat mengharapkan adanya kerjasama seperti PKM ini yang berkelanjutan, sehingga dapat membina dan mengembangkan potensi santriwati dalam rangka menciptakan lapangan kerja bagi santriwati dan lulusan Pesantren Puteri Yatama Mandiri.

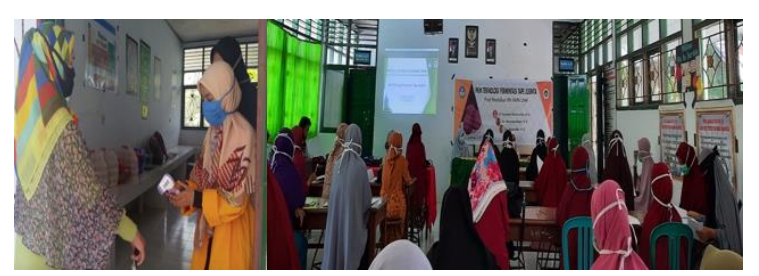

(A)

Gambar 2. Pengukuran suhu tubuh peserta oleh Tim PKM (A) dan pembatasan jarak peserta dalam ruangan (B)

Seluruh rangkaian Pelaksanaan kegiatan PKM mengikuti protokol kesehatan, yakni pemeriksaan suhu tubuh baik Tim Pelaksana maupun peserta, penggunaan masker serta pembatasan jarak antara peserta (Gambar 2).

Keberhasilan kegiatan pelatihan tersebut dinilai mulai dari persiapan, pelaksanaan hingga respons peserta dalam mengikuti kegiatan tersebut. Indikator yang digunakan untuk menilai keberhasilan kegiatan ini adalah : 1) tahap persiapan meliputi persiapan bahan pelatihan, pengurusan izin ruang kelas/laboratorium dan sekolah sebagai lokasi pelatihan, penentuan waktu dan peserta, 2) tahap pelaksanaan meliputi kehadiran peserta, materi pelatihan dan suasana pertemuan. Kegiatan pengabdian ini dianggap berhasil apabila kegiatan pelatihan mulai dari tahap persiapan dan tahap pelaksanaan berjalan lancar dan respons peserta selama pelatihan berlangsung dalam keseriusan yang tinggi.

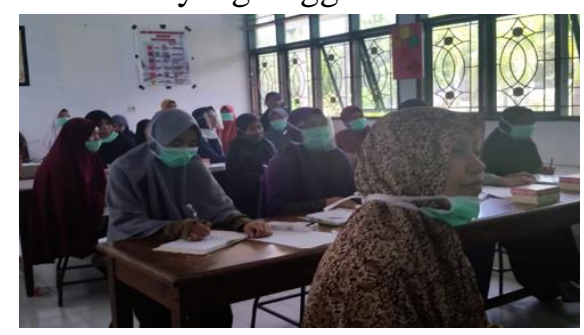

Gambar 3. Antusiasme peserta mengikuti kegiatan(A) dan pertanyaan wakasek terkait proses fermentasi TapeJusinta dan pengolahan lanjut menjadi Es krim (B)

Antusiasme peserta mengikuti kegiatan pelatihan (Ganbar 3) sangat tinggi, terbukti dari peran aktif peserta mengikuti penjelasan tim PKM disertai diskusi. Peserta aktif mengajukan pertanyaan terkait bioteknologi Tape Jusinta mulai dari jenis dan peranan mikroba dalam ragi tape lokal, proses fermentasi hingga kandungan gizi produk. Nampak pula antusiasme wakil kepala Sekolah SMA Pesantren Puteri Yatama, Bapak Abdul Rahim, S.Pd., M.Pd., mengajukan pertanyaan dan setia mengikuti rangkaian acara dari awal hingga akhir kegiatan

Setelah tahapan penjelasan materi dan diskusi, santriwati lanjut pada tahapan praktik langsung pembuatan Tape Jusinta. Kegiatan praktik mulai dari sterilisasi alat dan persiapan bahan baku ubi jalar ungu dan umbi ubi kayu sebagai substrat hingga proses fermentasi. Semua tahapan dilakukan dengan cara higienis dan aseptis.

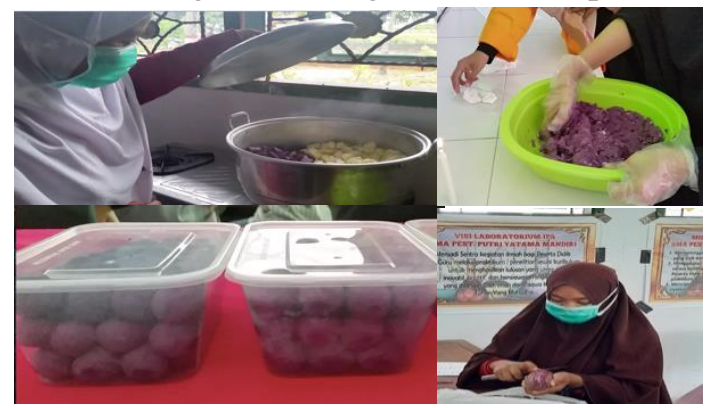

Gambar 4. Santriwati sedang praktek pembuatan Tape

Jusinta mulai dari pengupasan kulit ubi, pengukusan, pencampuran substrat ubi jalar dan ubi kayu lalu dibentuk bola-bola dan siap difermentasi selama 24 jam pada suhu ruang

Keberhasilan pelatihan dievaluasi melalui pemberian materi dan praktek mulai dari penyiapan substrat campuran umbi ubi jalar ungu dan umbi ubi kayu, proses fermentasi Tape Jusinta hingga uji organoleptik produk Tape Jusinta. Evaluasi dilakukan dengan pengisian angket tentang respons peserta terhadap produk sebelum pelatihan, respons peserta terhadap produk setelah pelatihan, respons peserta terhadap teknologi fermentasi Tape Jusinta dan respons peserta terhadap uji organoleptik yang meliputi atribut warna, aroma, tekstur, kekenyalan, rasa dan daya terima produk teknologi fermentasi Tape Jusinta. 
Semua penilaian kegiatan pelatihan dilakukan berdasarkan pengamatan langsung pada saat pelaksanaan hingga pengisian angket oleh peserta. Penilaian juga merujuk hasil setiap anggota tim pelatihan serta dapat diketahui dari hasil tanya jawab dengan peserta mengenai sejumlah faktor pendukung dan faktor penghambat.

Hasil respons peserta tentang pelatihan teknologi fermentasi Tape Jusinta terdiri atas; respons peserta terhadap produk Tape Jusinta sebelum pelatihan dan respons peserta terhadap proses pembuatan Tape Jusinta setelah pelatihan. Selain itu evaluasi kegiatan juga diperoleh dari respons guru terhadap teknologi fermentasi Tape Jusinta dalam pembelajaran di kelas.

Responden sebanyak 32 peserta dari kelompok santriwati kelas XII SMA dan 5 orang guru Pembina mata pelajaran. Semua responden bermukim di Pondok Pesantren Puteri Yatama Mandiri Kabupaten Gowa.

\section{a. Respons peserta terhadap Produk Tape Jusinta}

\section{Sebelum Pelatihan}

Sebelum pelatihan, responden diberikan angket yang berisi 12 pertanyaan yang terkait teknologi pembuatan Tape Jusinta yang telah diperkenalkan pada saat sosialisasi dan acara pembukaan kegiatan. Berdasarkan data yang dikumpulkan umumnya responden menyimak dengan baik uraian tentang produk fermentasi Tape Jusinta yang diperkenalkan oleh ketua Tim pelaksana kegiatan. Tanggapan peserta terhadap semua pertanyaan terkait produk Tape Jusinta, menunjukkan bahwa lebih banyak responden yang mengetahui istilah bioteknologi, bahan-bahan serta proses fermentasi Tape Jusinta. Responden kurang mengetahui jenis mikroba serta peranan setiap jenis dalam pembuatan Tape Jusinta. Responden juga kurang mengetahui cara-cara sederhana pembuatan dan penggunaan ragi pada fermentasi tape jusinta. Setengah dari jumlah peserta belum mengetahui perbedaan Tape Jusinta yang dibuat secara hiegienis dan tidak.

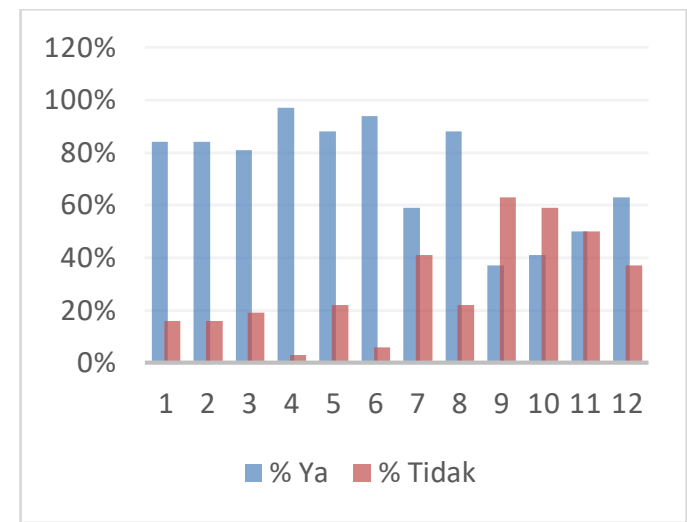

Gambar 5. Histogram respons peserta terhadap produk sebelum pelatihan

Data respons peserta terhadap Produk Tape Jusinta sebelum pelatihan menunjukkan bahwa sebanyak $97 \%$ responden mengenal arti hiegenis pada proses fermentasi Tape Jusinta. Sementara pengetahuan tentang jenis mikroba serta peranan setiap jenis dalam pembuatan Tape Jusinta hanya $37 \%$ yang mengetahui. Cara-cara sederhana pembuatan dan penggunaan ragi pada fermentasi tape hanya $41 \%$ peserta yang mengetahui .

Berdasarkan histogram Gambar 5 dapat disimpulkan bahwa pengenalan responden tentang Tape Jusinta memiliki respons yang sangat baik, namun tidak dengan jenis mikroba serta peranan setiap jenis mikroba dalam pembuatan Tape Jusinta. Pengetahuan tentang cara-cara sederhana pembuatan dan penggunaan ragi pada fermentasi tape juga belum dipahami.

b. Respons Peserta Terhadap Proses Pembuatan

Tape Jusinta Setelah Pelatihan

Adapun respons peserta terhadap proses pembuatan Tape Jusinta dikumpulkan dengan metode pengisisan angket yang terdiri dari 9 item pernyataan dengan bersumber 32 peserta sebagai responden. Adapun data respons peserta terhadap proses pembuatan Tape Jusinta setelah pelatihan dapat dilihat pada Gambar 6. 


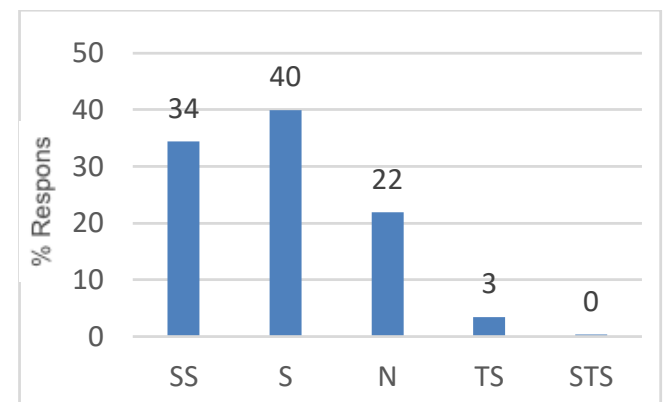

Gambar 6. Histogram respon peserta terhadap proses pembuatan Tape Jusinta setelah pelatihan

Berdasarkan histogram gambar 6 , diketahui bahwa sebanyak $40 \%$ peserta memberi respons setuju (S), sebanyak $34 \%$ peserta memberi respons sangat setuju (SS), sebanyak $22 \%$ peserta yang memberi respons netral $(\mathrm{N})$ dan $3 \%$ memberi respons tidak setuju (TS) namum tidak ada satupun responden dari peserta yang memberikan sangat tidak setuju (STS) terhadap proses pembuatan Tape Jusinta. Hal ini menunjukkan bahwa rata-rata respons peserta terhadap proses fermentasi Tape Jusinta berada dalam kategori setuju. Dengan demikian disimpulkan bahwa peserta dapat memahami dengan mudah proses pengolahan ubi jalar ungu dan umbi ubi kayu menjadi Tape Jusinta melalui teknologi fermentasi.

\section{c. Respons Guru Terhadap Teknologi Fermentasi Tape Jusinta dalam Pembelajaran di Kelas}

Evaluasi kegiatanu juga dilakukan setelah pelatihan, untuk menilai respons serta kemampuan para peserta pelatihan menerapkan hasil pelatihan yang didapatkan. Penerapan hasil pelatihan dapat dievaluasi dari tindak lanjut peserta pelatihan untuk membuat Tape Jusinta dan menilai produk yang dihasilkan melalui uji organoleptik. Setelah pelatihan responden dari peserta kelompok guru diberikan angket yang berisi 10 pertanyaan tentang penerapan Teknologi Tape Jusinta di dalam pembelajaran. Sebanyak $60 \%$ peserta dari kelompok guru menjawab bahwa teknologi fermentasi Tape Jusinta sesuai dengan kemampuan siswa dan cocok diterapkan dalam pembelajaran bioteknologi.

\section{d. Uji Organoleptik Produk Tape Jusinta}

Uji organoleptik menggunakan uji Hedonik dengan rentang skala numerik " 10 " untuk menilai sifat produk Tape Jusinta meliputi atribut warna, aroma, tekstur, rasa asam, rasa manis dan daya terima produk (Rahayu, 1998; Sobawale, et al., 2007). Adapun respons peserta terhadap uji organoleptik produk Tape Jusinta dikumpulkan dengan metode pengisian angket yang terdiri dari atribut warna, aroma, tekstur, rasa asam, rasa manis dan daya terima dengan bersumber 32 peserta sebagai responden. Berikut nampak peserta dengan serius mengisi angket sambil mencicipi produk Tape Jusinta yang dihasilkan dari campuran ubi jalar ungu dan umbi ubi kayu melalui teknologi fermentasi menggunakan ragi tape lokal.

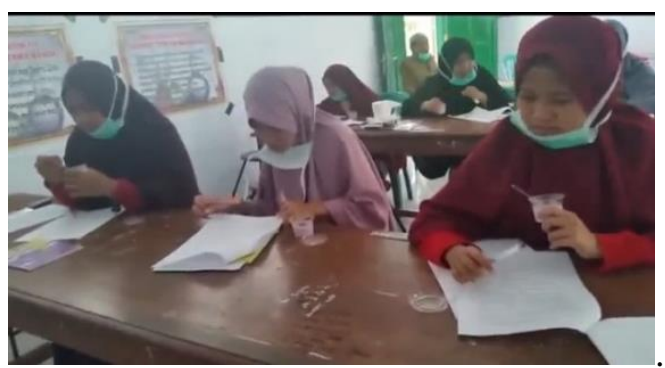

Gambar 7. Peserta pelatihan mengisi angket respons uji organoleptik produk Tape Jusinta

Hasil uji organoleptik peserta terhadap produk Tape Jusinta disajikan pada Gambar 8. Hasil penilaian organoleptik responden meliputi atribut warna, aroma, tekstur, rasa asam, rasa manis dan daya terima produk Tape Jusinta.

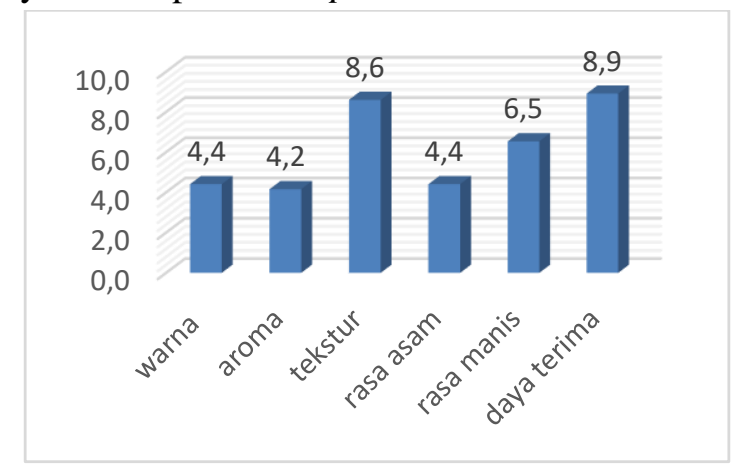

Gambar 8. Respons terhadap hasil pengolahan produk Tape Jusinta

Berdasarkan histogram gambar 8, didapatkan hasil penilaian organoleptik produk Tape Jusinta yaitu memiliki warna ungu muda dengan rata-rata 4.4, aroma alkohol kurang tajam dengan rata-rata 4.2, tekstur lembut dengan rata-rata 8.6, rasa sedikit asam dengan rata-rata 4.4 , rasa cukup manis 
dengan rata-rata 6.5 , dan daya terima produk oleh masyarakat adalah diterima baik dengan rata-rata 8.9. Hal ini membuktikan bahwa rata-rata respons dan daya terima peserta terhadap produk Tape Jusinta hasil fermentasi campuran ubi jalar ungu dan umbi ubi kayu sangat baik.

\section{KESIMPULAN}

Berdasarkan hasil kegiatan pengabdian kepada masyarakat disimpulkan bahwa respons santriwati kelas XII SMA Pesantren Puteri Yatama Mandiri terhadap kegiatan pengabdian PKM Teknologi Fermentasi Tape Jusinta sebelum dilakukan pelatihan menunjukkan bahwa sebanyak $97 \%$ responden mengetahui arti hiegenis pada proses fermentasi Tape Jusinta. Namun pengetahuan tentang jenis mikroba serta peranan setiap jenis mikroba dalam pembuatan Tape Jusinta hanya berkisar $37 \%$ yang mengetahui. Pengetahuan Cara-cara sederhana pembuatan dan penggunaan ragi pada fermentasi tape juga hanya $41 \%$ peserta yang mengetahui.

Respons peserta setelah dilakukan pelatihan Teknologi Fermentasi Tape Jusinta, menunjukkan bahwa rata-rata respons peserta terhadap proses fermentasi Tape Jusinta berada dalam kategori setuju. Dengan demikian disimpulkan bahwa peserta dapat memahami dengan mudah proses pengolahan ubi jalar ungu dan umbi ubi kayu menjadi Tape Jusinta melalui teknologi fermentasi. Sebanyak $60 \%$ peserta dari kelompok guru menjawab bahwa teknologi fermentasi Tape Jusinta sesuai dengan kemampuan siswa dan cocok diterapkan dalam pembelajaran bioteknologi.

Hasil uji organoleptik menunjukkan bahwa produk Tape Jusinta memiliki warna ungu muda dengan rata-rata 4.4, aroma alkohol kurang tajam dengan rata-rata 4.2 , tekstur lembut dengan ratarata 8.6, rasa sedikit asam dengan rata-rata 4.4 , rasa cukup manis dengan rata-rata 6.5 , dan daya terima produk oleh masyarakat adalah diterima baik dengan rata-rata 8.9. Hal ini membuktikan bahwa rata-rata respons dan daya terima peserta terhadap produk Tape Jusinta hasil fermentasi campuran ubi jalar ungu dan umbi ubi kayu sangat baik.

\section{UCAPAN TERIMA KASIH}

Ucapan terima kasih disampaikan kepada Rektor UNM dan Ketua Lembaga Penelitian dan Pengabdian Kepada Masyarakat UNM atas pendanaan, arahan dan pembinaanya selama proses kegiatan Pengabdian Masyarakat berlangsung. Demikian pula ucapan terima kasih disampaikan kepada Pimpinan, Ketua Yayasan, Kepala Sekolah dan Wakil Kepala Sekolah SMA serta seluruh santriwati SMA kelas XII Pesantren Puteri Yatama Mandiri Kabupaten Gowa Provinsi Sulawesi Selatan, yang telah memberi fasilitas dan partisipasinya mulai dari persiapan, pelaksanaan hingga evaluasi kegiatan PKM ini.

\section{DAFTAR PUSTAKA}

Ajayi, O. I.1, Ehiwuogu-Onyibe, J. 1, Oluwole, O. B.2, Jegede, A. A.2, Salami, T. A.1, Asieba, G. O.3, Chiedu, I. E.3, Suberu, Y. L.1, Aba, E. M.3, Dike, E. N.1, Ajuebor F. N.4 and Elemo, G. N.2, 2016. Production of fermented sweet potato flour using indigenous starter cultures. African Journal of Microbiology Research . Vol. 10(41), pp. 1746-1758

Badan Pusat Statistik. 2017. Kabupaten Gowa dalam Angka. Badan Pusat Statistik, Kabupaten Gowa.

Direktorat Kelembagaan Dikti. 2009. Pedoman Program Mahasiswa Wirausaha Bagi Kopertis dan PTS.

Khoirunnisa S, Ihartono, \& Resnawaty R. 2015. Pemenuhan Kebutuhan Pendidikan Anak Asuh di Panti Sosial Asuhan Anak, Prosiding KS: Riset \& PKM. Vol. 2 No. $1: 1-146$

Muhiddin, N. H., Ramlawati, N. A. Yanti \& A. Mun'im. 2018. Fermentasi Campuran Umbi Ubi Kayu dan Ubi Jalar menggunakan Ragi Tape Lokal sebagai Bahan Pembuatan Es Krim. Laporan Akhir Penelitian Strategi Nasional Institusi, UNM-DRPM DIKTI.

Muhiddin, N. H., Ramlawati, N. A. Yanti \& A. Mun'im. 2018. Mutu Organoleptik Hasil Fermentasi Campuran Umbi Ubi Jalar dan Umbi Ubi Kayu menggunakan Ragi Tape Lokal. Prosiding Seminar Nasional LP2M UNM. 


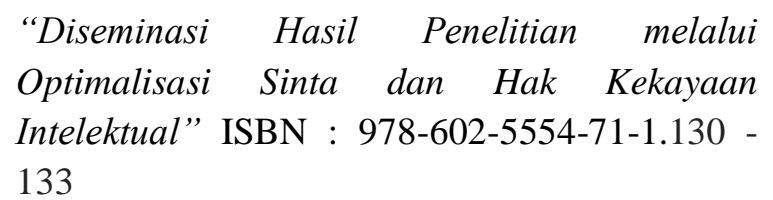

Muhiddin, N. H., Ramlawati, N. A. Yanti \& A. Mun'im. 2019. Analisis Kuantitatif Mikroorganisme pada Ragi Lokal dan Daya Terima Tape Jusinta yang dihasilkan. BioWallaceae : Jurnal Peneltian Biologi. Vol.6, No.2 : 1007-1016

Rahayu, W. P. 1998. Penuntun Praktikum Penilaian Organoleptik. Jurusan Teknologi Pangan dan Gizi. Fakultas Pertanian, Institut Pertanian Bogor, Bogor.

Sobawale, A. O., T.O. Olurin and O.B. Oyewale. 2007. Effect of Lactic Acid Bacteria culture Fermentation of Cassava on Chemical and Sensory Characteristics of Fufu Flour. African Journal of Biotechnology. Vol. 6 (16) , pp 1954-1958.

Saudagarnews.id, Gowa, 2018. Jadi Daerah Produksi Kacang dan Ubi Tertinggi, Gowa Berhasil Suplai Pemenuhan Pangan di Sulsel.

Siswoyo, B. 2009. Pengembangan Jiwa Kewirausahaan di Kalangan Dosen dan Mahasiswa, Jurnal Ekonomi Bisnis. Vol.14, No. $2: 114-123$ 